\title{
Movements and post-release mortality of juvenile sea turtles released from gillnets in the lower Cape Fear River, North Carolina, USA
}

\author{
Jessica E. Snoddy* ${ }^{*}$ Amanda Southwood Williard \\ University of North Carolina Wilmington, 601 S. College Road, Wilmington, North Carolina 28403, USA
}

\begin{abstract}
North Carolina coastal waters are an important seasonal foraging habitat for juvenile green Chelonia mydas and Kemp's ridley Lepidochelys kempii sea turtles. Sea turtle mortality due to incidental capture in gillnets is a topic of great concern in this region, and fisheries regulations have been implemented to minimize sea turtle bycatch. Current regulations are based on estimates of fisheries-related sea turtle mortality derived from analyses of fishing effort, observed bycatch, and strandings data. Information regarding the health status of sea turtles at the time of release and documentation of post-release mortality are necessary in order to refine the mortality estimates used to govern management decisions. The primary goals of the present study were to use satellite telemetry to monitor post-release movements of sea turtles released from gillnets, document post-release mortality, and evaluate the feasibility and reliability of using blood biochemistry data collected at the time of capture to predict post-release mortality. Satellite telemeters were deployed on, and blood samples were collected from, juvenile green and Kemp's ridley sea turtles released from a $14 \mathrm{~cm}$ mesh gillnet set in shallow waters (1 to $5 \mathrm{~m}$ deep) in the lower Cape Fear River, North Carolina, USA. Twelve of 14 turtles released from the gillnet stayed in the lower Cape Fear River throughout the post-release tracking duration. We documented 1 confirmed and 3 suspected post-release mortalities. Blood chemistry analyses revealed differences in plasma ion $\left(\mathrm{K}^{+}, \mathrm{Cl}^{-}, \mathrm{Na}^{+}\right)$and lactate levels between the turtle that died (confirmed mortality) and all other study animals, suggesting that these variables could serve as chemical predictors of post-release mortality.
\end{abstract}

KEY WORDS: Lepidochelys kempii · Chelonia mydas · Satellite telemetry · Blood chemistry · Fisheries

\section{INTRODUCTION}

Sea turtles face many threats to their survival, including loss of nesting and foraging habitat, egg and hatchling predation, pollution, and other anthropogenic factors such as boat strikes and encounters with recreational and commercial fishing gear (Lutcavage et al. 1997). Efforts to protect sea turtles on nesting beaches are well-established (Eckert et al. 1999), but in-water threats remain a topic of great concern for sea turtle conservationists and policy-makers. Bycatch of sea turtles in commercial fishing gear has been identified as a significant source of mortality contributing to population declines (Magnuson et al. 1990, Lewison et al. 2004). Knowledge of sea turtle habitat and the potential for overlap with fisheries, as well as an understanding of the impacts of incidental entanglement on the behavior and survivability of sea turtles, are high priorities for management. Mitigation of fisheries interactions with juvenile sea turtles is of particular importance, as protection of this age class is thought to be critical to recovery efforts (Crouse et al. 1987, Read et al. 2004).

North Carolina coastal waters serve as an important foraging ground for juvenile sea turtles in the summer months (Epperly et al. 1995a,b). The most common 
species found in North Carolina are loggerhead Caretta caretta, green Chelonia mydas and Kemp's ridley Lepidochelys kempii (Epperly et al. 1995a). Entanglement of sea turtles in gillnets has become a critical concern for fisheries managers in this region, primarily as a result of mass stranding events that coincided with peak fishing effort for the Pamlico Sound flounder fishery in 1999 and 2000 (Gearhart 2001, Santora 2003, Price 2005). The deep-water gillnet fishery in Pamlico Sound was shut down in 2002 due to interactions with sea turtles (National Marine Fisheries Servcie 2002), and fishing effort is now restricted to shallow waters in this region (North Carolina Division of Marine Fisheries [NC DMF] Proclamation M-182009, www.ncfisheries.net/procs/index.html). In other areas of the state, such as the lower Cape Fear River, full time gillnet attendance requirements have been implemented during periods when sea turtle abundance is highest (May-December) so that fishers may immediately remove any turtles that become entangled (NC DMF Proclamations M-12-2009, M-17-2009, M-21-2009, M-25-2009, www.ncfisheries.net/procs/ index.html). Although designed to minimize the impact of entanglement on sea turtles, these restriction effectively close the summer and fall flounder fishery in this region because fishermen are unwilling to stay with their nets throughout the $12 \mathrm{~h}$ of a typical set.

The numerous management measures implemented to either minimize the detrimental effects of gillnet entanglement or to reduce sea turtle interactions with gillnets reflect the concern that mortality due to interactions with this gear type contributes significantly to sea turtle population declines. Fisheries observer programs provide important information regarding the number of sea turtles that die while entangled in gillnets, but post-release mortality of sea turtles released alive from gillnets is more difficult to determine (Gearhart 2001). Severe physiological disruptions and injuries incurred while entangled in gillnets could result in undocumented deaths (Lutcavage \& Lutz 1991, Harms et al. 2003, Stabenau \& Vietti 2003, Snoddy et al. 2009) and an underestimation of sea turtle mortality due to gillnet interactions. Blood biochemistry profiles have been used to assess the physiological impacts of gillnet entanglement on sharks (Manire et al. 2001) and to infer the fate of sharks released from longline fishing gear (Moyes et al. 2006, Hight et al. 2007), but to date there has been little effort to integrate physiological data into estimates of post-release mortality for sea turtles captured in gillnets. Sea turtles subjected to enforced submergence exhibit alterations in blood lactate concentration indicative of metabolic acidosis, as well as shifts in blood ion concentrations (sodium $\left[\mathrm{Na}^{+}\right]$, chloride $\left[\mathrm{Cl}^{-}\right]$, and potassium $\left[\mathrm{K}^{+}\right]$) indicative of disruptions in cellular homeostasis and compensation for respiratory acidosis (Stabenau et al. 1991, Harms et al. 2003, Stabenau \& Vietti 2003, Snoddy et al. 2009). When combined with post-release monitoring of movements and behavior, these blood parameters may provide valuable insight into the potential for post-release mortality for sea turtles released from fishing gear.

The use of satellite telemetry to document postrelease mortality for sea turtles released from pelagic fishing gear has met with varying degrees of success (Chaloupka et al. 2004, Swimmer et al. 2006, Sasso \& Epperly 2007). Determining the post-release fate (survival or mortality) of sea turtles using satellite telemetry is complicated by the fact that cessation of a satellite signal may be attributable to factors other than mortality, such as tag failure or tag loss due to shedding (Hays et al. 2003, Chaloupka et al. 2004, Seney 2008). Confirmation of a mortality event inferred from satellite transmission patterns is more feasible in an inshore environment, as opposed to the open ocean, as there is a greater likelihood that carcasses may wash up on land (Murphy \& Hopkins-Murphy 1989). The purpose of the present study was to evaluate the use of satellite telemetry in combination with blood chemistry profiles as a means to identify post-release mortality events for sea turtles released from gillnets in an inshore environment. Our specific objectives were to (1) use satellite telemetry to monitor post-release movements of sea turtles released from inshore gillnets in the lower Cape Fear River, (2) document postrelease mortality events based on satellite transmission patterns and location of stranded turtles, and (3) evaluate the feasibility of using blood biochemistry data collected at the time of capture to predict post-release mortality of sea turtles.

\section{MATERIALS AND METHODS}

Field procedures. Sea turtles were captured in a $14 \mathrm{~cm}$ mesh gillnet set at depths of 1 to $2 \mathrm{~m}$ in the lower Cape Fear River during daylight hours (06:00 to 16:00 h) from May through October of 2007 (Table 1, Fig. 1). This area is dominated by marshes, small coves and bays, sand islands, and tidal creeks. The dominant marsh grasses are Spartina sp., Juncus roemerianus, and Salicornia sp., and the bottom substrate is a mud and sand mix. The gillnet remained in water for a maximum of $6 \mathrm{~h}$ and was attended at all times, as per NC DMF regulations (Proclamation M-13-2007), so that we could document time of capture. A total of 18 sea turtles (14 green turtles and 4 Kemp's ridley turtles) were captured over the course of 40 gillnet sets. Captured turtles remained entangled in the gillnet for up to $240 \mathrm{~min}$ and were closely monitored throughout the duration of en- 
Table 1. Lepidochelys kempii and Chelonia mydas. Descriptive information for Kemp's ridley $\left(\mathrm{Lk}_{;} \mathrm{n}=3\right)$ and green $(\mathrm{Cm} ; \mathrm{n}=9) \mathrm{sea}$ turtles captured in the lower Cape Fear River, NC, USA. Satellite transmitters were deployed on, and blood samples were collected from, these turtles. SCLnn: straight carapace length, notch to notch; $T_{\mathrm{w}}$ : water temperature

\begin{tabular}{|c|c|c|c|c|c|c|c|c|c|}
\hline Turtle ID & $\begin{array}{l}\text { Capture } \\
\text { date }\end{array}$ & $\begin{array}{c}\text { Capture location } \\
\left({ }^{\circ} \mathrm{N},{ }^{\circ} \mathrm{W}\right)\end{array}$ & $\begin{array}{l}\text { SCLnn } \\
(\mathrm{cm})\end{array}$ & $\begin{array}{c}T_{\mathrm{w}} \\
\left({ }^{\circ} \mathrm{C}\right)\end{array}$ & $\begin{array}{c}\text { Entanglement } \\
\text { time (min) }\end{array}$ & $\begin{array}{c}\text { Type of } \\
\text { entanglement }\end{array}$ & $\begin{array}{l}\text { Time on } \\
\text { boat (min) }\end{array}$ & $\begin{array}{c}\text { Track } \\
\text { duration (d) }\end{array}$ & Fate \\
\hline Lk 1 & 6 Jun 2007 & $\begin{array}{l}33.9505^{\circ} \\
77.9457^{\circ}\end{array}$ & 29.9 & 27.3 & 45 & Carapace & 110 & 13 & Survivor \\
\hline Lk 2 & 30 Jun 2007 & $\begin{array}{l}33.9017^{\circ} \\
77.0347^{\circ}\end{array}$ & 37.6 & 28.5 & 107 & Neck & 66 & 8 & $\begin{array}{l}\text { Confirmed } \\
\text { mortality }\end{array}$ \\
\hline Lk 4 & 31 Aug 2007 & $\begin{array}{l}33.9238^{\circ} \\
77.9589^{\circ}\end{array}$ & 38.1 & 28.7 & 30 & Flipper, head & 54 & 10 & $\begin{array}{c}\text { Suspected } \\
\text { mortality }\end{array}$ \\
\hline $\mathrm{Cm} 1$ & 7 Jun 2007 & $\begin{array}{l}33.9315^{\circ}, \\
77.9723^{\circ}\end{array}$ & 32.2 & 26.9 & 63 & Flippers & 79 & 17 & Survivor \\
\hline $\mathrm{Cm} 2$ & 8 Jun 2007 & $\begin{array}{l}33.9361^{\circ} \\
77.9664^{\circ}\end{array}$ & 29.3 & 28.2 & 218 & Neck, flippers & 93 & 23 & $\begin{array}{c}\text { Suspected } \\
\text { mortality }\end{array}$ \\
\hline $\mathrm{Cm} 3$ & 14 Jun 2007 & $\begin{array}{l}33.9493^{\circ} \\
77.9574^{\circ}\end{array}$ & 28.6 & 27 & 132 & Neck, carapace & 71 & 16 & $\begin{array}{c}\text { Suspected } \\
\text { mortality }\end{array}$ \\
\hline $\mathrm{Cm} 5$ & 20 Aug 2007 & $\begin{array}{l}33.9267^{\circ} \\
77.9539^{\circ}\end{array}$ & 27.6 & 32.3 & 143 & Neck, flippers & 82 & 13 & Survivor \\
\hline $\mathrm{Cm} 8$ & 8 Sep 2007 & $\begin{array}{l}33.9181^{\circ} \\
77.9709^{\circ}\end{array}$ & 28.8 & 27.8 & 30 & Flippers & 60 & 20 & Survivor \\
\hline $\mathrm{Cm} 10$ & 19 Sep 2007 & $\begin{array}{l}33.8942^{\circ}, \\
77.9591^{\circ}\end{array}$ & 30.6 & 23.3 & 30 & Neck, flippers & 64 & 6 & Survivor \\
\hline $\mathrm{Cm} 11$ & 26 Sep 2007 & $\begin{array}{l}33.9215^{\circ} \\
77.9678^{\circ}\end{array}$ & 29.6 & 28.3 & 20 & Carapace, flippers & 51 & 16 & Survivor \\
\hline $\mathrm{Cm} 12$ & 19 Oct 2007 & $\begin{array}{l}33.8900^{\circ} \\
77.9632^{\circ}\end{array}$ & 27.0 & 27.4 & 212 & $\begin{array}{c}\text { Neck, carapace, } \\
\text { flippers }\end{array}$ & 54 & 25 & Survivor \\
\hline $\mathrm{Cm} 13$ & 19 Oct 2007 & $\begin{array}{l}33.8900^{\circ} \\
77.9632^{\circ}\end{array}$ & 32.2 & 27.4 & 88 & Neck, carapace & 58 & 42 & Survivor \\
\hline
\end{tabular}

tanglement. If a turtle remained submerged for longer than 20 min or appeared to be in danger of drowning due to airway or swimming restriction, it was immediately removed from the gillnet. The type of interactions with gillnet (i.e. entanglement around neck, flipper, or carapace) was noted for each turtle. Environmental variables (water temperature $\left[T_{\mathrm{w}}\right]$, air temperature $\left[T_{\mathrm{a}}\right]$, salinity) were recorded at the capture site, and GPS locations for capture sites were documented.

Upon removal from the gillnet, turtles were brought on board our boat and placed in a $16 \times 43 \mathrm{~cm}$ padded plastic bin. Turtles were shaded from direct sunlight and periodically sprayed with seawater. We immediately obtained a $4 \mathrm{ml}$ blood sample from the cervical sinus using heparinized vacuum tubes and a 21 gauge $\times 3.8 \mathrm{~cm}$ needle (BD Vacutainer). Samples were stored on ice for 30 to $240 \mathrm{~min}$ before centrifuging at $7000 \mathrm{rpm}$ for 10 min using a portable field centrifuge (Zip Spin, LW Scientific). Plasma was stored in cryogenic tubes on dry ice, transferred to a $-80^{\circ} \mathrm{C}$ freezer, and analyzed within 4 mo. We measured the straight carapace length notch to notch (SCLnn) and straight carapace width (SCW), and inserted passive induced transponder (PIT) tags above the left front flipper for future identification.
We used a 2-part fast-setting marine epoxy (PowerFast, Powers Fasteners) to attach satellite transmitters (SPOT 5, Wildlife Computers) (length $\times$ width $\times$ height: $7.9 \times 4.9 \times 1.8 \mathrm{~cm} ; 90 \mathrm{~g})$ and VHF radio beacons (SI-2F, Holohil Systems) $(3.5 \mathrm{~cm}$ length $\times 1.0 \mathrm{~cm}$ diameter; $11 \mathrm{~g})$ to 14 of the 18 turtles we captured. We did not deploy transmitters on turtles for which the total mass of transmitters and epoxy was $>5 \%$ of the turtle's mass in air, as calculated from a length-weight power regression (NOAA Beaufort Laboratory, unpubl. data). Estimated masses of captured turtles ranged from 1.5 to $6.7 \mathrm{~kg}(3.7 \pm 1.4 \mathrm{~kg}, \bar{X} \pm \mathrm{SD}$, where $\bar{X}$ is the mean $)$. Prior to transmitter attachment, the vertebral scutes of the carapace were cleared of barnacles, cleaned with acetone to remove biofouling, lightly sanded with sand paper, and given a final acetone rinse. The VHF radio beacon was attached to the third or fourth vertebral scute with the antenna facing toward the head of the turtle and laying flat on the carapace surface. The satellite transmitter was secured to the first and second vertebral scutes of the carapace, and the epoxy base for the transmitter was molded such that drag effects would be reduced (National Marine Fisheries Service SEFSC 2008). While epoxy was setting, we examined turtles for net-inflicted external injuries and tested 


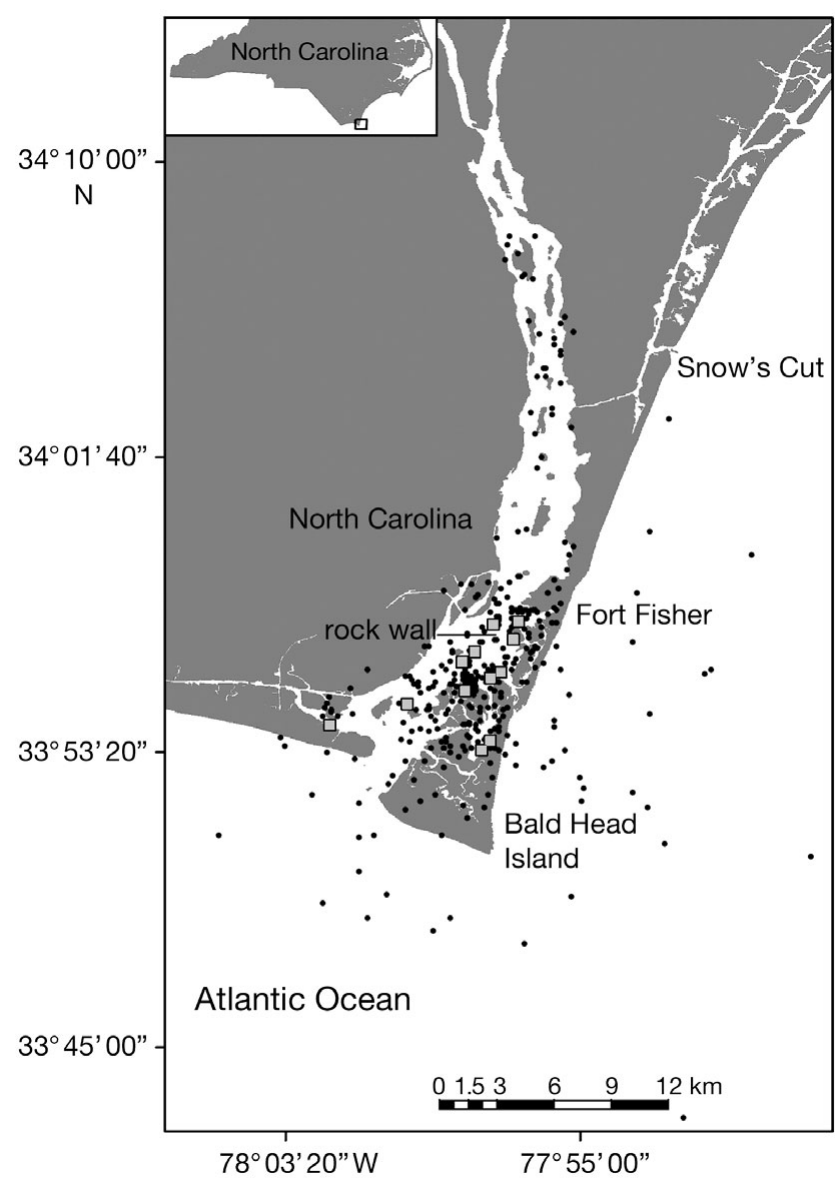

Fig. 1. Study area. ( $\square$ ): capture locations of all turtles captured (Lepidochelys kempii and Chelonia mydas; $\mathrm{n}=18$ ). $(\bullet)$ : filtered location data for all turtles that remained in Cape Fear River, NC, USA, for track duration $(\mathrm{n}=12)$

reflex responses to a gentle touch to the eye, nose, and tail (Snoddy et al. 2009). Turtles were on board the boat for 10 to $110 \mathrm{~min}(58 \pm 26.6 \mathrm{~min}, \bar{X} \pm \mathrm{SD})$ and were released within $10 \mathrm{~m}$ of the capture site.

Analysis of location data. Transmitters were programmed to prioritize transmission of location data in order to maximize battery life and monitoring duration. The satellite transmitters were programmed for a $24 \mathrm{~h}$ duty cycle so that they transmitted location data to CLS America network satellites whenever turtles were at the surface. Transmitter positions were assigned to 1 of 6 location classes (LC 3, 2, 1, 0, A and B) by CLS America based on the number of transmissions received and the angle and speed of satellites relative to the transmitter at the time of transmissions. For location classes $3,2,1$, and 0 , the location accuracies are $<250,500$, and $1500 \mathrm{~m}$, and $>1500 \mathrm{~m}$, respectively, and for location classes A and B, no location accuracy is assigned (CLS America 2007). The percentage of transmissions of each location class for all turtles combined was calculated (Fig. 2).
Location data were downloaded and analyzed using the Satellite Tracking and Analysis Tool (STAT) program available at www.seaturtle.org (Coyne \& Godley 2005). We applied a multi-step filtering procedure to exclude implausible locations from analyses of turtle movements and home range. CLS America diagnostic data were used to exclude locations that had a satellite pass time of $<240 \mathrm{~s}$ based on the repetition rate of satellite transmitters ( 1 uplink per $60 \mathrm{~s}$ ) as determined by the manufacturer (Wildlife Computers 2006). We found that positions with $<4$ uplinks for a given pass resulted in very poor location classes, so these were eliminated from the data set. The remaining locations were plotted sequentially on a map and filtered based on speed and distance thresholds established in previous studies of sea turtle movement patterns in coastal environments (McClellan \& Read 2010). Locations that were separated by distances that could not be covered at a swim speed of $<5 \mathrm{~km} \mathrm{~h}^{-1}$ were excluded from analysis, as were locations that would have required turtles to pass implausibly over land barriers (Luschi et al. 1998). Because transmissions from land, and particularly high-quality location class transmissions along the shoreline, may indicate a stranding event all landbased transmissions were carefully analyzed. If lowquality land-based transmissions were interspersed over time with transmissions from water, these points were excluded from analysis. Filtered data were then mapped in ArcGIS (version 9.2).

In addition to monitoring satellite transmissions, we also attempted to track turtles via VHF radio telemetry. A VHF receiver (TR-5, Telonics) and directional $\mathrm{H}$ antenna (RA-2AK, Telonics) or omni-directional antenna

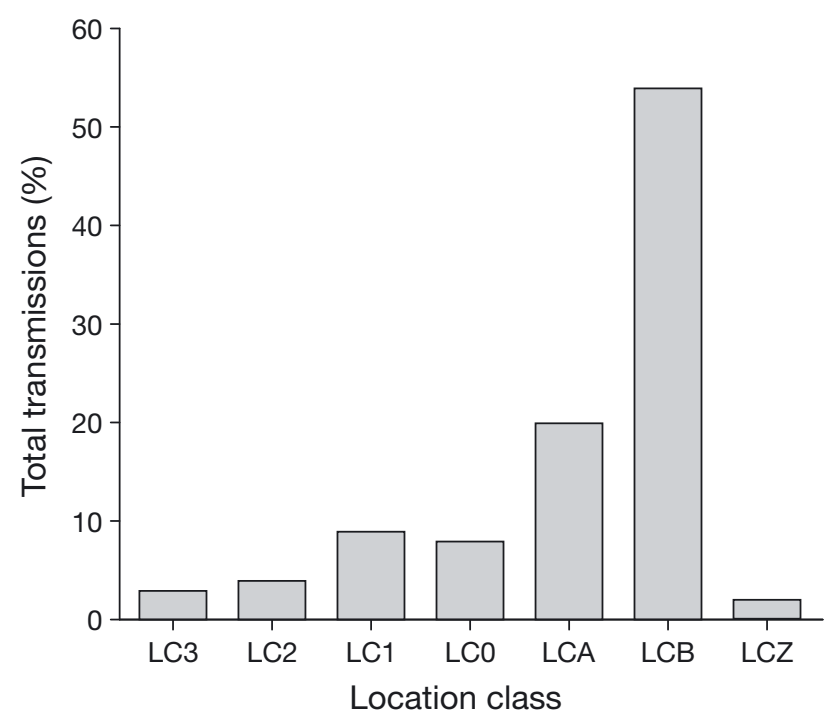

Fig. 2. Proportions of location classes of the total transmissions received for all turtles (L. kempii and C. mydas; $\mathrm{n}=14$ ) tagged in the lower Cape Fear River, NC, USA 
(RA-5A, Telonics) were used to search for radio signals at least $3 \times$ per week from land-based positions throughout the course of the study. We also searched for VHF radio signals from boats while deploying and monitoring the gillnet along the submerged rock wall study site. The VHF receiver and antennae configurations we used had a detection range of approximately $1.6 \mathrm{~km}$ at our study site. We did not detect VHF signals from any of the turtles during our monitoring efforts, so we have no data to report for VHF tracking efforts.

Assessment of mortality. Satellite transmissions received during the $30 \mathrm{~d}$ following release from the gillnet were analyzed for patterns indicative of mortality based on (1) documented behavioral patterns of green and Kemp's ridley turtles in nearshore environments, (2) behaviors associated with compromised health, and (3) knowledge of the process of decay and onshore stranding of sea turtle carcasses. We predicted that a mortality event would be reflected by satellite transmission patterns that deviated from previously documented patterns (Godley et al. 2003, McClellan \& Read 2010) and were consistent with the process of decay and putrefaction (criteria described in the following 3 paragraphs). The $30 \mathrm{~d}$ monitoring period was chosen because turtles are exposed to numerous threats in their marine environment, and the more time that passes the more difficult it becomes to attribute mortality to the gillnet interaction. We reasoned that physiological and behavioral consequences of gillnet entanglement and vulnerability to other threats would be greatest in the first few weeks following entanglement.

Previous satellite telemetry studies of sea turtles in coastal environments have demonstrated that short surfacing intervals (<1 min), particularly during warm summer months (Nelson 1996), and low profile surfacing patterns result in receipt of low-quality location class data (LC A or B) (Godley et al. 2003, McClellan $\&$ Read 2010). Sea turtles that are injured, fatigued, or have experienced large disruptions in blood biochemistry due to enforced submergence may require extensive amounts of time at the surface to recover (Lutz \& Bentley 1985, Stabenau \& Vietti 2003). We interpreted prolonged periods of numerous, high-quality location class transmissions that occurred in the hours to days immediately following release as representative of a surface recovery period. We compared the percentage of high-quality location class transmissions (LC 3, 2, 1) received during the first $24 \mathrm{~h}$ following release to the percentage of high-quality location transmissions received in the subsequent $72 \mathrm{~h}$ for each turtle using a repeated-measures ANOVA. Significance was set at $\mathrm{p}<0.05$.

We predicted that mortality events would be reflected by alterations in the quality and quantity of location data transmitted via satellite. Specifically, we predicted that satellite transmissions would cease for several days following a mortality event as the carcass sank below the surface, but that frequent, high-quality location class transmissions (LC 3, 2, 1) would resume for a brief period when putrefaction and build-up of gases caused the carcass to temporarily float back to the surface (National Research Council 1990, Epperly et al. 1996). Increases in the quality and frequency of satellite transmissions along the shoreline were interpreted as a possible shore stranding event. In such cases, a VHF radio receiver and directional $\mathrm{H}$ antenna were used to search for the VHF radio beacon signal so that we could locate the carcass and verify mortality.

Turtles that did not display transmission patterns indicative of a mortality event (i.e. temporary cessation of signal followed by period of high-quality transmissions) within $30 \mathrm{~d}$ of release were considered survivors. Turtles that displayed satellite transmission patterns indicative of mortality but for which we did not locate a carcass were categorized as suspected mortalities. Turtles that displayed satellite transmission patterns indicative of mortality and for which we located a carcass were categorized as confirmed mortalities. Carcasses that were located were examined for indications of boat strike, predation, and gut impaction. We compared the percentage of high-quality locations (LC 3, $2,1)$ for the entire track duration of suspected mortalities and confirmed mortalities to those of survivors using a Student's $t$-test.

Blood chemistry. Plasma lactate concentrations were determined using a commercially available, 2-step lactate reagent kit (Pointe Scientific) and standard spectrophotometric techniques (Lambda 25 UV/Vis; Perkin Elmer). Lactate standards of 5, 10, 15, and $50 \mathrm{mmol} \mathrm{l}^{-1}$ were used to generate a regression equation to describe the relationship between absorbance (abs) and lactate concentration ([Lactate] $\mathrm{mmol} \mathrm{l}^{-1}=$ [abs 0.0309]/0.0299; $\left.\mathrm{r}^{2}=0.9995\right)$. All plasma samples were run in duplicate, and the mean of duplicate absorbance values was used to estimate plasma lactate concentrations using the standard regression. Buffer solutions and $15 \mathrm{mmol}^{-1}$ standard solutions were assayed simultaneously with plasma samples as a quality-control measure. Plasma concentrations of $\mathrm{Na}^{+}, \mathrm{Cl}^{-}$, and $\mathrm{K}^{+}$ were analyzed by spectrophotometry at a veterinary diagnostic laboratory (Antech Diagnostics).

We conducted a multivariate analysis (Plymouth Routines In Multivariate Ecological Research, PRIMER 6, PRIMER-E) using lactate, $\mathrm{Na}^{+}, \mathrm{Cl}^{-}$, and $\mathrm{K}^{+}$as variables to assess differences in blood biochemistry of turtles with different post-release fates (i.e. confirmed mortality, suspected mortality, and survivor). Multivariate statistical techniques are commonly used in ecological studies to assess similarity or dissimilarity in species composition, community structure, and ecolog- 
ical patterns between data sets (Clarke 1993, 1999). For the present study, we used these techniques to assess whether variations in blood composition at the time of release could be used to distinguish turtles that died post-release from survivors.

Results from Snoddy et al. (2009) demonstrated a statistically significant relationship between these blood variables and entanglement time (i.e. time spent in net). Thus, entanglement time was included as a factor in the multivariate analysis. Body size, body temperature, and salinity were not included in the analysis, as Pearson correlations between these factors and blood variables were weak $(\mathrm{r}<0.50)$ and not statistically significant ( $p$ > 0.05) (Snoddy et al. 2009). We created a resemblance matrix based on Euclidean distance similarity and conducted a non-metric multi-dimensional scaling (NMDS) analysis to visually represent the relatedness of blood biochemistry profiles for individual turtles. The NMDS plot reflects the overall similarities and dissimilarities between blood profiles of turtles from different fate categories. Points that lie close to each other in the plot show high similarity in blood profiles based on the multiple variables used in analysis. We then conducted an analysis of similarity (ANOSIM) to determine if there was a statistically significant difference in blood biochemistry profiles for turtles in each fate category, across entanglement times. Differences in blood biochemistry profiles of confirmed mortalities, suspected mortalities, and survivors were deemed statistically significant at $\mathrm{p}<0.05$.

\section{RESULTS}

\section{Movements}

During the period when our study was conducted (May and October 2007) there was low rainfall, and we recorded high salinities (32-39 PSU), consistently clear water, and $T_{\mathrm{w}}$ of 27.3 to $32.3^{\circ} \mathrm{C}$. Ten of 18 turtles were captured along a partially submerged, human engineered rock wall that divides 2 northern bays from the river to the west (Fig. 1). Fourteen sea turtles were tracked for 6 to $42 \mathrm{~d}(17.0 \pm 8.9, \bar{X} \pm \mathrm{SD})$ following release from the gillnet (Table 1). Filtered location data indicate that the majority of sea turtles remained in the lower Cape Fear River for the tracking duration. A small percentage $(16 \%)$ of low-quality locations that passed the filter criteria placed turtles in the ocean around the river mouth or off the eastern shore of the barrier island complex of southeastern North Carolina. Approximately $95 \%$ of filtered high-quality location data (LC 3, 2, 1) for all but 2 turtles (green turtles Cm 3 and $\mathrm{Cm} \mathrm{13)} \mathrm{were} \mathrm{limited} \mathrm{to} \mathrm{within} \mathrm{a} 3 \mathrm{~km}$ radius of the turtle's capture site (Fig. 1).
Turtles $\mathrm{Cm} 3$ and $\mathrm{Cm} 13$ migrated out of the Cape Fear River following release from the gillnet. Turtle $\mathrm{Cm}$ 3, captured on 14 June 2007, remained in the lower Cape Fear River for $3 \mathrm{~d}$ following release and then exited the river and moved north along the North Carolina coastline for $10 \mathrm{~d}$. The last transmission from turtle Cm 3 was received on 27 June 2007 from the lower White Oak River near Swansboro, NC. Turtle Cm 13, captured on 19 Oct 2007, exited the Cape Fear region $20 \mathrm{~d}$ after release and traveled south along the coasts of North Carolina and South Carolina for $22 \mathrm{~d}$ before transmissions ceased. The last transmission was received from east of the mouth of St. Helena Sound, SC on 24 November 2007.

\section{Post-release mortality}

Turtles that were tracked post-release $(n=14)$ were entangled in the gillnet for 20 to $218 \mathrm{~min}(85.5 \pm$ $67.7 \mathrm{~min}, \bar{X} \pm \mathrm{SD}$ ). Juvenile green and Kemp's ridley turtles released from the gillnet were classified as confirmed mortalities $(n=1)$, suspected mortalities $(n=3)$, or survivors $(n=10)$, based on patterns observed in satellite transmissions post-release. The one turtle for which we directly documented mortality by recovering the carcass (Kemp's ridley turtle Lk 2, captured 30 June 2007, entangled for $107 \mathrm{~min}$ ) displayed a pattern of satellite transmissions that met our criteria for mortality. This turtle had cuts in the skin at the shoulder, injuries on its face from barnacles that were ripped off by the gillnet, and pink coloration to the neck where the gillnet was wrapped around it. Between 30 June 2007 and 4 July 2007 we received 14 transmissions from this turtle. Following a LC B transmission on 4 July 2007, there was a period of several days during which no signals were received. Transmissions resumed at 23:09 $\mathrm{h}$ on 6 June 2007, and all further transmissions were of high location class quality (Fig. 3, Fig. 4a). The rising tide likely stranded the carcass in the marsh, with high tide at $01: 18 \mathrm{~h}$ on 7 June 2007 . The carcass, with transmitter still attached, was located within $1 \mathrm{~km}$ of the gillnet capture site on 7 June 2007. When the carcass was discovered, the tide was low but rising. Subsequent necropsy of the carcass yielded no evidence of boat strike, predation, or gut impaction, and this turtle was classified as a confirmed mortality.

Turtles Lk 4, Cm 2, and Cm 3 displayed transmission patterns suggestive of a mortality event. Carcasses were not located for these turtles, so they were classified as suspected mortalities. Turtle Lk 4 was released on 31 August 2007 after a 30 min gillnet entanglement with bleeding around the claw caused by the gillnet. Several high-quality location class data points were received from this turtle in the initial 2 days post- 


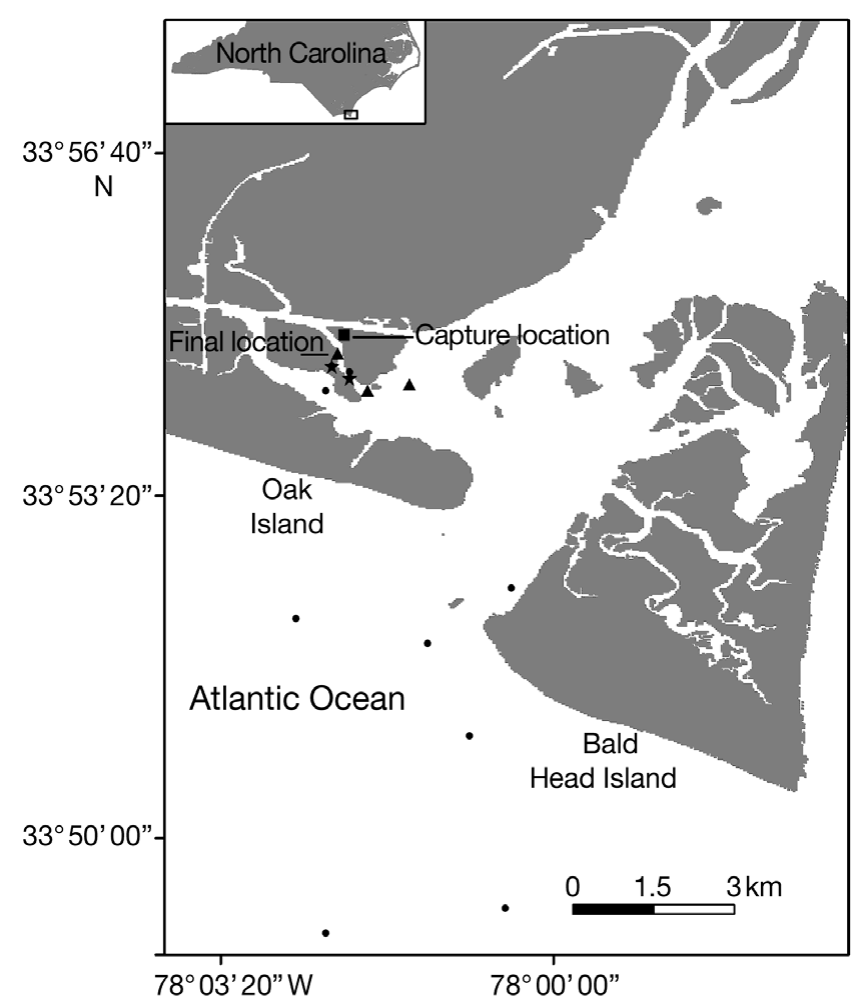

Fig. 3. Lepidochelys kempii. Filtered location data for turtle Lk 2, confirmed mortality. ( $\star$ ): LC 3 locations; (₫): LC 2 locations; $(\boldsymbol{\bullet})$ : LC 1 locations; $(\bullet)$ : LC A and LC B locations. For a description of location classes see 'Materials and methods: Analysis of location data'

release, a pattern suggestive of a lengthy surface recovery period (Fig. 4b). Signals received over the course of the next several days revealed that the turtle moved $24 \mathrm{~km}$ up river from the capture site. Turtle Lk 4 was the only turtle that ventured north of Snow's Cut in the Cape Fear River. High-quality location signals were reported on the low to rising tide in the river north of Snow's Cut on 6 September 2007, with more high-quality signals received the following day (7 September 2007). We checked repeatedly for the VHF radio beacon for this turtle over the course of these $2 \mathrm{~d}$, but did not detect any signals. Satellite transmissions for this turtle ceased on 9 September 2007, with the last location reported on the river side of Snow's Cut. Although the transmission pattern for this turtle was different from that observed for the other turtles that were confirmed or suspected mortalities (i.e. no disappearance and reappearance of signal), the up-river movements and increase in high-quality transmissions from shoreline locations towards the end of the tracking period led us to conclude that the turtle probably died.

Turtle Cm 2 was released after a 218 min gillnet entanglement on 8 June 2007. Prior to release, this tur- tle had demonstrated weakened reflex responses (i.e. lethargic response to gentle touch to the eye, nose, and tail), low activity levels onboard the boat and had minor injuries from small barnacles on the soft tissue that were ripped off by the gillnet. Upon release from the boat, the turtle sank slowly beneath the water surface with no active flipper strokes. High winds and choppy seas prevented us from visually relocating and recapturing this turtle; however, we picked up its VHF radio beacon within minutes of release. We received numerous high-quality location class data points from this turtle during the $8 \mathrm{~h}$ following release, which indicated that it was at the surface for an extended period of time. We continued to receive daily low-quality transmissions from this turtle until 19 June 2007. After this date, we received high-quality location class data intermittently for the next several months. Transmissions received on 30 June 2007 (LC 3), 9 August 2007 (LC 2), 18 August 2007 (LC 3), and 10 October 2007 (LC 1) were clustered along the partially submerged rock wall within $500 \mathrm{~m}$ distance of the site where we had captured the turtle. Although this area was checked frequently, we were unable to detect the VHF radio signal for this turtle or locate a carcass or shed transmitter. Intermittent transmissions likely reflect the exposure of the transmitter, either detached or still attached to a carcass, at low tide. The poor condition of this turtle, behavior of turtle at release, and pattern of satellite transmissions led us to categorize this turtle as a suspected mortality.

Transmission patterns for turtle $\mathrm{Cm} 3$ led us to believe that this turtle had died post-release. This turtle was released from the gillnet with no external injuries. Transmissions from this turtle ceased after a period of approximately $9 \mathrm{~d}$ (14 to 22 June 2007) spent traveling northwards along the coast of North Carolina from the capture site in the lower Cape Fear to just off the coast of Emerald Isle close to Bogue Inlet. Transmissions resumed 4 d later on 26 June 2007, and several high-quality location class transmissions were received from within the lower White Oak River adjacent to Swansboro, NC. The pattern of signal disappearance and reappearance close to the shoreline several days later suggests that this turtle died and stranded temporarily along the shoreline due to tidal flow (Fig. 4d). We received the strongest signals on the rising tide, which may indicate that the carcass was washed ashore temporarily. We were unable to recover a carcass before transmissions ceased permanently.

The remaining 10 turtles on which we deployed satellite and VHF radio transmitters did not display transmission patterns indicative of a mortality event as defined by our criteria, and were thus classified as survivors. Most of these turtles had only minor (scrapes) to moderate (shallow cuts) external injuries. However, 


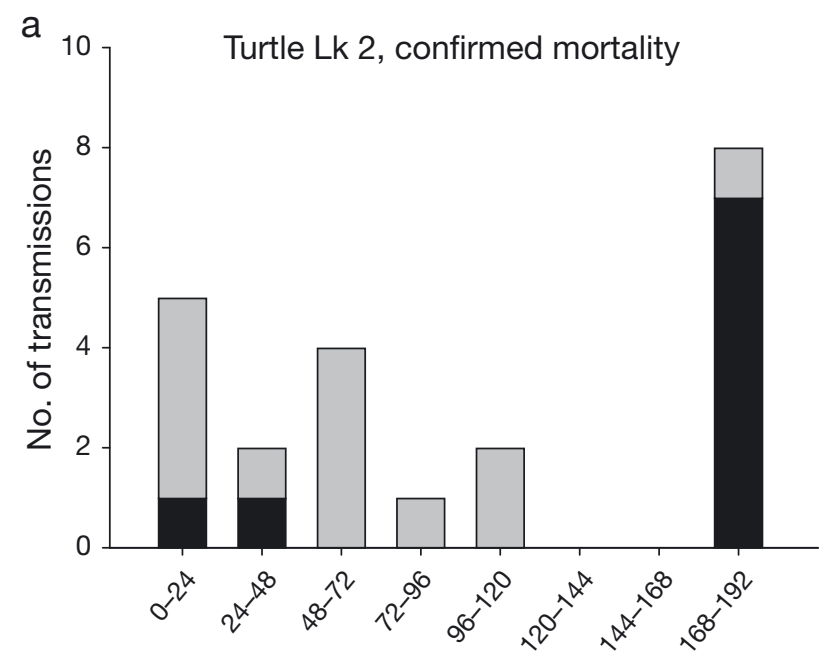

Hours post-release

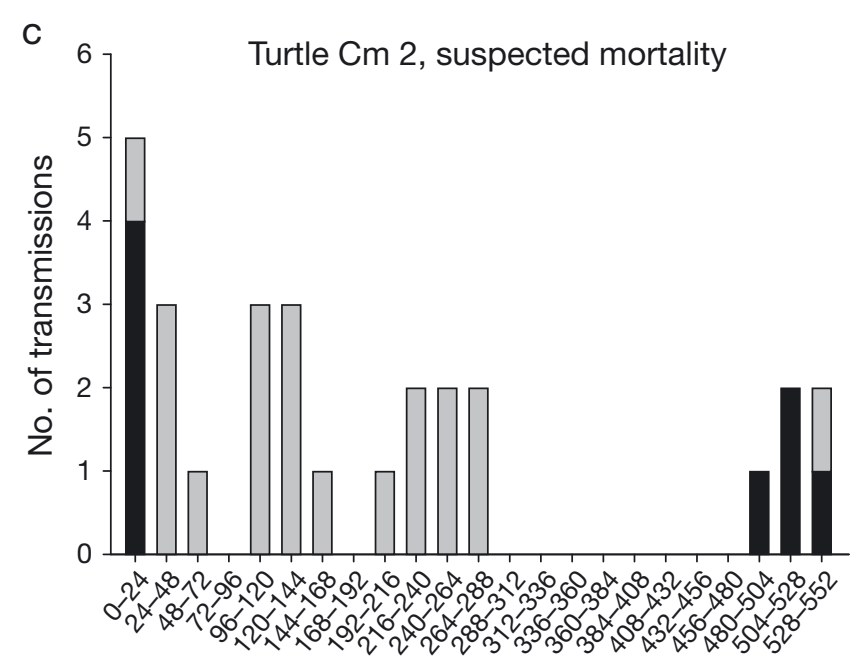

Hours post-release

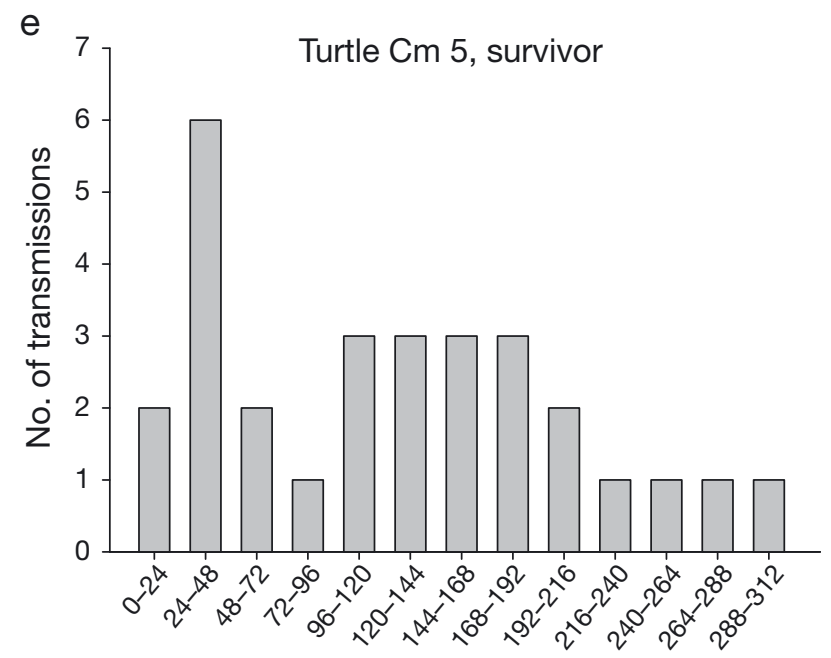

Hours post-release

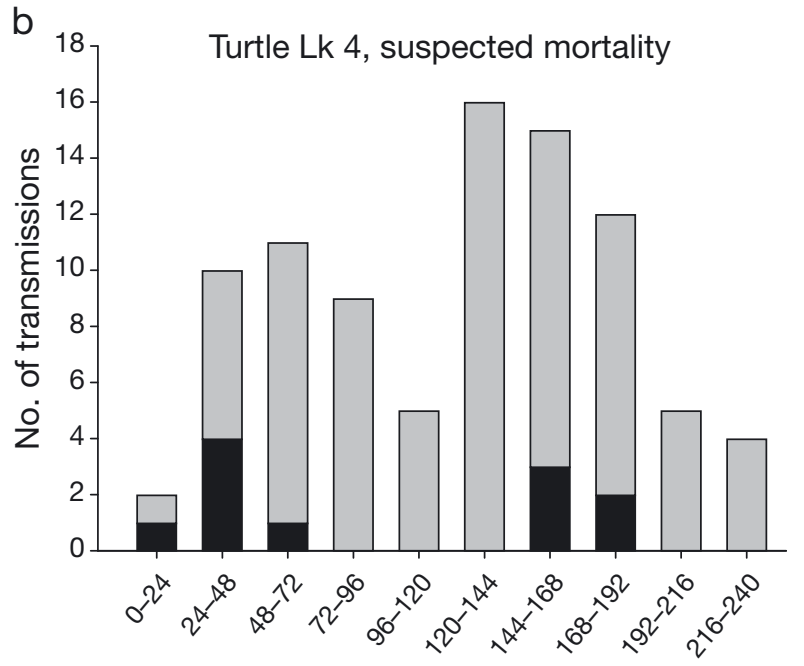

Hours post-release

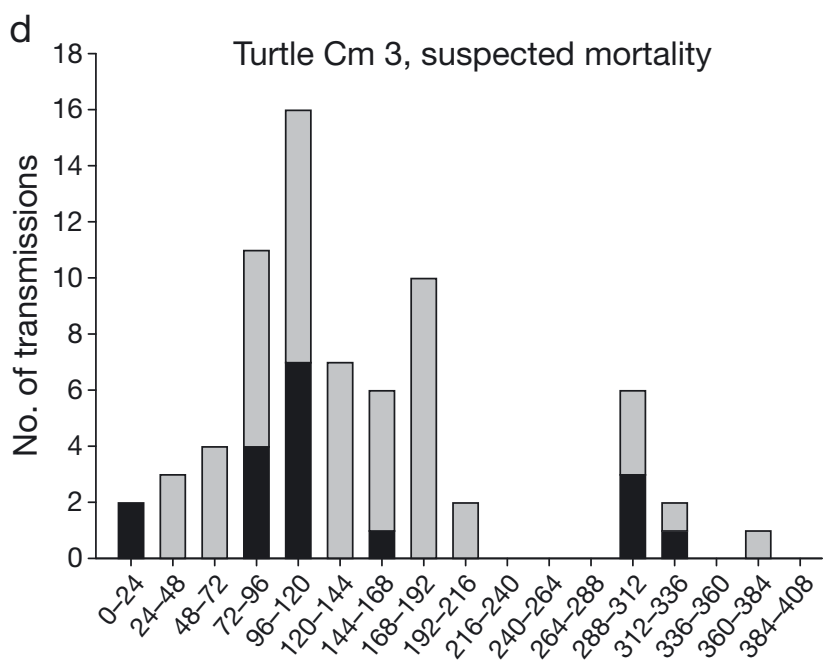

Hours post-release

Fig. 4. Number and quality of transmissions received for each $24 \mathrm{~h}$ period tracked post-release for (a) turtle Lk 2 (confirmed mortality), (b) turtle Lk 4 (suspected mortality), (c) turtle Cm 2 (suspected mortality), (d) turtle Cm 3 (suspected mortality), and (e) turtle $\mathrm{Cm} 5$ (survivor). Black bars represent highquality (HQ) location data and white bars represent low-quality (LQ) location data. For a description of location classes see 'Materials and methods: Analysis of location data' 
turtles Cm 1 (bleeding at the shoulders and flipper bruising from the net) and Cm 5 (shoulder cuts and bruising around the neck and flippers from the net and a pink flush of soft tissue) had more severe injuries. Satellite transmissions received from survivors were predominantly of low-quality location class, sometimes with intermittent high-quality signals received throughout the monitoring period (Fig. 4e). There was a significantly lower percentage of high-quality transmissions for the entire tracking period for the survivors ( $n=10)$ compared with the confirmed and suspected mortalities $(n=4)(p=0.017)$. For several turtles classified as survivors (turtles $\mathrm{Cm} \mathrm{1,Cm} \mathrm{4,} \mathrm{Cm} \mathrm{7,} \mathrm{Cm} \mathrm{8),} \mathrm{the}$ $24 \mathrm{~h}$ period immediately following release was characterized by receipt of several high-quality location class transmissions. The results from the repeated measures ANOVA for all tagged turtles $(\mathrm{n}=14)$ indicated that there was a significantly higher percentage of highquality transmissions (LC 1,2,3) within the first $24 \mathrm{~h}$ following release compared with the subsequent $72 \mathrm{~h}$ $(\mathrm{p}=0.008)$.

\section{Blood chemistry}

Blood samples were obtained from 12 of the 14 tagged turtles. Values for plasma concentrations of lactate, $\mathrm{Na}^{+}, \mathrm{Cl}^{-}$, and $\mathrm{K}^{+}$for turtles of all fate categories are presented in Table 2 . The confirmed mortality, turtle Lk 2, had a very high plasma lactate concentration (19.4 $\mathrm{mmol} \mathrm{l}^{-1}$ ) compared with baseline values for this species reported in the literature $\left(0.7 \mathrm{mmol} \mathrm{l}^{-1}\right)$ (Stabenau et al. 1991). This turtle also had plasma concentrations of $\mathrm{Na}^{+}$(332 $\mathrm{mEq} \mathrm{l}^{-1}$ ) (mEq: milliequivalent) that were approximately $2 \times$ the mean of suspected mortalities (161 $\left.\pm 3 \mathrm{mEq} \mathrm{l}^{-1}, \bar{X} \pm \mathrm{SD}\right)$ and survivors $\left(165.1 \pm 5.5 \mathrm{mEq}{ }^{-1}, \bar{X} \pm \mathrm{SD}\right)$, plasma concen- trations of $\mathrm{Cl}^{-}\left(380 \mathrm{mEq} \mathrm{l}^{-1}\right.$ ) that were approximately $3 \times$ higher than the mean for suspected mortalities $\left(116.3 \pm 12.6 \mathrm{mEq} \mathrm{l} \mathrm{l}^{-1}, \bar{X} \pm \mathrm{SD}\right)$ and survivors (118.6 \pm $7.0 \mathrm{mEq} \mathrm{l}^{-1}, \bar{X} \pm \mathrm{SD}$ ), and the highest plasma concentration of $\mathrm{K}^{+}\left(8.8 \mathrm{mEq}^{-1}\right)$ in this study (Table 2).

The multivariate NMDS analysis showed 2 distinct groupings based on blood biochemistry: the suspected mortalities and survivors grouped together, whereas the confirmed mortality (turtle Lk 2) was isolated at a distance (i.e. there was a high degree of dissimilarity in blood biochemistry between the confirmed mortality and all other turtles) (Fig. 5). However, results from the ANOSIM revealed no statistically significant difference blood biochemistry (lactate, $\mathrm{Na}^{+}, \mathrm{Cl}^{-}$, and $\mathrm{K}^{+}$) between fate categories (global $\mathrm{R}=0.41, \mathrm{p}=0.188$ ).

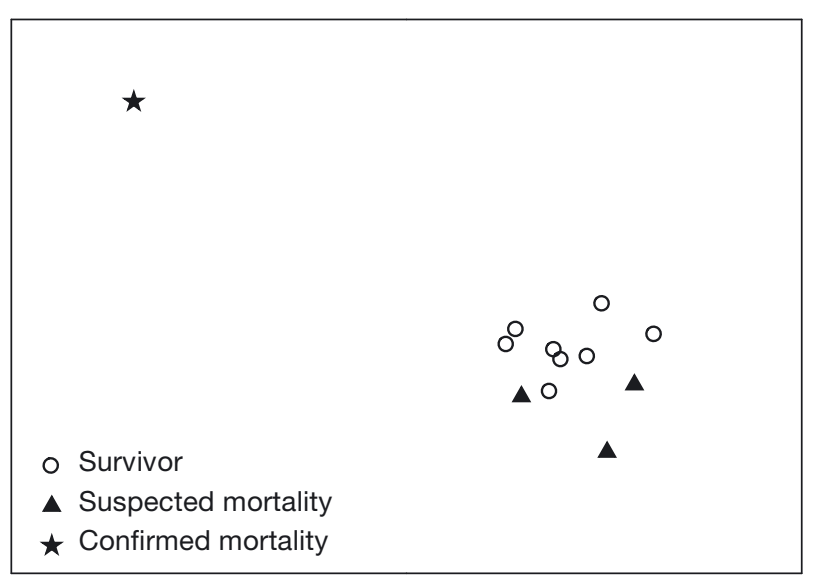

Fig. 5. Non-metric multidimensional scaling (NMDS) plot representing relative relationship of blood biochemistry profiles for individual turtles (Lepidochelys kempii and Chelonia mydas; $\mathrm{n}=12$ ). Analysis includes time spent in net as a factor. $(\star)$ : confirmed mortality; $(\mathbf{\Delta})$ : suspected mortalities; $(\mathrm{O})$ : survivors. (MDS stress $=0.01$ )

Table 2. Lepidochelys kempii and Chelonia mydas. Blood biochemistry of confirmed mortality $(L$. kempii; $\mathrm{n}=1)$, suspected mortalities (L. kempii and C. mydas; $\mathrm{n}=3$ ) and survivors (L. kempii and C. mydas; $\mathrm{n}=8$ ) captured in the lower Cape Fear River, NC, May-October 2007. Baseline (control or resting) values reported in the literature are presented for comparison. $\bar{X}:$ mean; mEq: milliequivalent

\begin{tabular}{|c|c|c|c|c|c|}
\hline \multirow{2}{*}{$\begin{array}{l}\text { Blood } \\
\text { parameter }\end{array}$} & \multirow{2}{*}{$\begin{array}{l}\text { Confirmed } \\
\text { mortality }\end{array}$} & \multirow{2}{*}{$\begin{array}{c}\text { Suspected mortalities } \\
\bar{X} \pm \mathrm{SD} \text { (range) }\end{array}$} & \multirow{2}{*}{$\begin{array}{c}\text { Survivors } \\
\bar{X} \pm \text { SD (range) }\end{array}$} & \multicolumn{2}{|c|}{ Mean baseline values } \\
\hline & & & & L. kempii & C. mydas \\
\hline Lactate $\left(\mathrm{mmol} \mathrm{l}^{-1}\right)$ & 19.4 & $\begin{array}{l}33.7 \pm 16.6 \\
(17.1-50.2)\end{array}$ & $\begin{array}{c}25.4 \pm 9.4 \\
(13.1-36.7)\end{array}$ & $0.7^{\mathrm{a}}$ & $0.5^{\mathrm{c}}, 1.1^{\mathrm{e}}$ \\
\hline $\mathrm{K}^{+}\left(\mathrm{mEq} \mathrm{l^{-1 }}\right)$ & 8.8 & $\begin{array}{l}5.8 \pm 0.3 \\
(5.6-6.1)\end{array}$ & $\begin{array}{l}6.6 \pm 1.4 \\
(5.2-8.5)\end{array}$ & $6.3^{\mathrm{a}}, 3.6^{\mathrm{b}}$ & $5.3^{\mathrm{d}}, 5.0^{\mathrm{f}}$ \\
\hline $\mathrm{Cl}^{-}\left(\mathrm{mEq} \mathrm{l}^{-1}\right)$ & 380 & $\begin{array}{c}116.3 \pm 12.6 \\
(103-128)\end{array}$ & $\begin{array}{c}118.6 \pm 7.0 \\
(111-131)\end{array}$ & $112.2^{\mathrm{a}}, 115.2^{\mathrm{b}}$ & $113^{\mathrm{d}}, 109.0^{\mathrm{f}}$ \\
\hline $\mathrm{Na}^{+}\left(\mathrm{mEq} \mathrm{l} \mathrm{l}^{-1}\right)$ & 332 & $\begin{array}{c}161.0 \pm 3.0 \\
(158.0-164.0)\end{array}$ & $\begin{array}{c}165.1 \pm 5.5 \\
(159.0-172.0)\end{array}$ & $140.5^{\mathrm{a}}, 153.3^{\mathrm{b}}$ & $172^{\mathrm{d}}, 152.2^{\mathrm{f}}$ \\
\hline
\end{tabular}




\section{DISCUSSION}

The primary goal of the present study was to investigate post-release mortality of juvenile sea turtles released from coastal gillnets using a combination of satellite telemetry and blood biochemistry analysis. The benefit to using this approach is that it allows an assessment of post-release fate that incorporates health status at the time of release and post-release behavior. The importance of integrating multiple lines of evidence in determining post-release mortality was highlighted by the results of our study, as an assessment of mortality based solely on either telemetry results or biochemistry results would have led to alternate conclusions (discussed below).

Four of the 14 turtles tagged in the present study exhibited satellite transmission patterns indicative of mortality based on our a priori criteria (cessation and reappearance of satellite signal and/or frequent highquality transmissions from shoreline), and we recovered the carcass for one of those turtles (turtle Lk 2, confirmed mortality), which permitted verification of our criteria for inferring mortality based on satellite transmission patterns in a nearshore environment. Due to our inability to confirm death for 3 of the 14 turtles, we cannot discount alternate explanations for the transmission patterns observed, such as tag shedding or tag failure.

Interestingly, results from the multivariate analysis of blood parameters demonstrated that suspected mortalities aligned more closely with survivors than with the confirmed mortality (Fig. 5). One interpretation of this result is that our reading of satellite patterns for suspected mortalities was flawed, and that the patterns observed were due to factors other than death. Another interpretation is that suspected mortalities did not die as a result of the gillnet entanglement documented in the present study, but as a result of a second entanglement. McClellan \& Read (2010) report a high incidence of multiple interactions between juvenile green turtles and various types of fishing gear in Core and Pamlico Sounds, NC, based on satellite transmission patterns of tagged turtles (i.e. high-quality location data) and communication from fishermen. We observed no consistent pattern in satellite transmission for the suspected mortalities to suggest that a second entanglement occurred (i.e. a secondary period of high-quality transmissions prior to disappearance and reappearance of signal); nevertheless it is an intriguing possibility. If turtles that we classified as suspected mortalities based on satellite transmission patterns died as a result of a second entanglement, analysis of blood biochemistry prior to that event would not necessarily reflect the cause of death. Integration of the biochemistry results with the satellite telemetry data pro- vides insight into the potential post-release fates of turtles that would not be possible using just one or the other technique.

With regards to the confirmed mortality (turtle Lk 2), satellite telemetry and blood biochemistry results were in agreement. The NMDS analysis of blood biochemistry grouped suspected mortalities and survivors together, but the confirmed mortality was distinct from all other turtles (Fig. 5). The ANOSIM did not detect a statistically significant difference between blood biochemistry of the confirmed mortality and all other turtles, but this is likely due to low sample size (there was only one confirmed mortality). Plasma lactate levels for turtles in all fate categories were much higher than baseline levels reported for green and Kemp's ridley turtles (Berkson 1966, Butler et al. 1984, Stabenau et al. 1991), indicating severe metabolic acidosis as a result of entanglement (Snoddy et al. 2009). Reptiles have a high capacity for anaerobic metabolism (Bennett 1982), so metabolic acidosis in and of itself may not result in post-release mortality. The confirmed mortality, however, also exhibited elevated levels of plasma ions $\left(\mathrm{Na}^{+}, \mathrm{Cl}^{-}, \mathrm{K}^{+}\right)$in comparison to suspected mortalities, survivors, and baseline values reported in the literature (Stabenau et al. 1991, Carminati et al. 1994, Aguirre et al. 1995, Snoddy et al. 2009). In response to a decrease in blood $\mathrm{pH}$, cells may release $\mathrm{K}^{+}$into the bloodstream in exchange for $\mathrm{H}^{+}$ions. $\mathrm{A} \mathrm{K}^{+}-\mathrm{H}^{+}$ exchanger has been proposed as a buffering mechanism to counteract blood acidosis in sea turtles (Rose 1977, Lutz 1997, Stabenau \& Vietti 2003, Hoopes et al. 2000), but the membrane proteins that may serve this function have not yet been identified in the cells of sea turtles. Increased plasma $\mathrm{Cl}^{-}$may reflect increased activity of the chloride shift mechanism of red blood cells in response to respiratory acidosis. Accumulation of $\mathrm{CO}_{2}$ and its subsequent conversion to $\mathrm{HCO}_{3}{ }^{-}$during periods of struggling in a net could result in upregulation of $\mathrm{Cl}^{-}-\mathrm{HCO}_{3}{ }^{-}$exchange across the red blood cell membrane. Stabenau \& Vietti (2003) found an increase in $\mathrm{Na}^{+}$and $\mathrm{Cl}^{-}$in sea turtles forcibly submerged multiple times in shrimp trawls, and suggested that this may reflect a volume regulatory response by red blood cells. In the case of the confirmed mortality for our study, increased levels of $\mathrm{Na}^{+}$and $\mathrm{Cl}^{-}$may simply reflect a large salt load incurred by ingestion or aspiration of seawater while in the net. Turtle Lk 2 was tightly entangled around the neck, and was removed from the net before the end of the $6 \mathrm{~h}$ net set due to an inability to reach the surface. It is very likely that this turtle may have ingested or aspirated seawater as it struggled to breathe. The osmoregulatory challenges posed by taking on a large salt load, in combination with 
metabolic and respiratory disruptions, may have contributed to the cause of death.

The physiological status of sea turtles removed from gillnets depends on factors other than time spent in net. Snoddy et al. (2009) noted that blood parameters indicative of metabolic disruption and stress could be affected by the nature of the interaction, particularly for entanglements in which surfacing behavior and breathing of the turtle was impeded. The depth at which turtles were entangled in the net and the portion of body entangled (i.e. neck, flippers, shell) had an effect on levels of blood lactate and corticosterone (Snoddy et al. 2009). Given the strong influence of temperature on physiological processes of reptiles, it would be reasonable to assume that $T_{\mathrm{w}}$ experienced during entanglement could also affect blood biochemistry. Warmer temperatures during entanglement were expected to result in a greater degree of physiological disruption compared with cooler temperatures. Snoddy et al. (2009), however, found no statistically significant effect of $T_{\mathrm{w}}$ during entanglement on lactate, $\mathrm{Na}^{+}, \mathrm{Cl}^{-}$, or $\mathrm{K}^{+}$. The $T_{\mathrm{w}}$ experienced by all turtles during entanglement in this study ranged from 26.9 to $32.3^{\circ} \mathrm{C}(27.8 \pm 2.0, \bar{X} \pm \mathrm{SD})$, and the $T_{\mathrm{w}}$ experienced during entanglement by the one confirmed mortality was $28.5^{\circ} \mathrm{C}$. Perhaps our sample size was too low and the range of $T_{\mathrm{w}}$ experienced during entanglement too narrow to make inferences regarding the role of temperature in physiological disruption and post-release mortality.

We had initially planned to monitor satellite transmissions for signs of mortality for $30 \mathrm{~d}$ following release from the gillnet. Unfortunately, track durations for 12 of the 14 turtles were 23 d or less. For turtles classified as survivors, the satellite transmissions up until the time when transmissions ceased did not show a pattern indicative of mortality as defined by our criteria. Therefore, we concluded that the short track durations were due to premature shedding of the transmitters rather than mortality. Short track durations have been documented for juvenile greens during the summer months in Core and Pamlico Sounds, NC (17154 d) (McClellan \& Read 2010) and for immature Kemp's ridley sea turtles in the Gulf of Mexico (12-57 d) (Seney 2008). Rapid growth rates of juvenile sea turtles at summer foraging habitats could contribute to short transmitter retention times, as the epoxy bond with the carapacial scutes may become weakened with the increase in scute diameter. Variation in habitat may also impact transmitter retention time. We captured 10 turtles along a partially submerged rock wall, where they were likely foraging on algae or invertebrates. Abrasion against the rocky substrate may have contributed to premature shedding of transmitters. Transmitters deployed on green turtles in Core and
Pamlico Sounds, NC (McClellan \& Read 2010) and in the lower Cape Fear River, NC, were retained for a longer duration when deployed late in the season (October-November), just prior to fall migration. In our study, turtles Cm 12 and Cm 13 were tagged in midOctober, and their track durations (25 and $42 \mathrm{~d}$, respectively) were longer than the average track duration for all turtles (17.1 d).

The satellite transmitters used in this study were capable of reporting haulout statistics (i.e. percent of time at surface and submerged); however, use of this function required 30 to $35 \%$ more battery power. We opted to prioritize transmission of location data only, so that we could extend the monitoring period for as long as possible. Unfortunately, we did not foresee the short retention times of transmitters. Had we used the haulout function, it would have provided useful data to support our interpretation of satellite transmission patterns. Nevertheless, we feel that the use of location class data, although indirect, still provides meaningful information regarding time spent at surface and implications for post-release recovery periods and mortality events. We documented a significantly higher percentage of highquality transmissions in the first $24 \mathrm{~h}$ post-release compared with the subsequent $72 \mathrm{~h}$ for all turtles. This observation indicates that turtles spent an extended period of time at the surface following release from gillnets. This behavior could potentially contribute to postrelease mortality, as turtles at the surface are more susceptible to boat strike or predation.

As with all studies that involve remote monitoring of wildlife, it is important to consider the impacts of instrument attachment on animal behavior and, in our case, post-release mortality (Watson \& Granger 1998, Wilson \& McMahon 2006). Our procedures for deploying satellite transmitters on turtles were in accord with National Oceanic and Atmospheric Administration (NOAA) recommendations and guidelines (National Marine Fisheries Service SEFSC 2008) and were permitted by the NOAA Office of Protected Resources (permit \#1572). Blood samples collected after transmitter attachment showed no statistically significant differences in blood lactate, ions, enzymes, or corticosterone levels compared with blood samples collected immediately after turtles were removed from the gillnet (Snoddy et al. 2009). This provides some evidence that the tagging procedure did not have a negative physiological impact on turtles. It is difficult to say whether the transmitters had an effect on post-release behavior, as there are no published data on movements and behavior of green and Kemp's ridley turtles in the lower Cape Fear River with which to compare our results.

Based on our data, we estimate that post-release mortality of sea turtles released from shallow-set gillnets 
could be as low as $7.1 \%$ and as high as $28.6 \%$. It is important to acknowledge that these figures are for soak times of $4 \mathrm{~h}$ or less, and nets are typically left to soak overnight in the North Carolina coastal gillnet fishery. Blood samples taken from green sea turtles entangled in the gillnet show significant positive relationships between entanglement time and blood biochemical parameters indicative of restraint stress and hypoxia (Snoddy et al. 2009). Longer entanglement times would be expected to result in greater physiological disruption, longer recovery periods, and, potentially, higher rates of post-release mortality rates. We found that a combination of blood biochemistry analysis and satellite telemetry data provided the most comprehensive means of assessing post-release mortality for sea turtles captured in gillnets, and encourage the simultaneous use of both techniques in future studies. Field measurements of lactate, ions, and other biochemical parameters are feasible, now that clinical point-of care analyzers are widely available (Harms et al. 2003, 2007). Given the low sample size of our study, additional data are needed to characterize the biochemical signature associated with delayed mortality due to gillnet entanglement. Should such a signature be identified, this would provide managers with a powerful tool for assessing post-release mortality and the potential impacts of gillnet interactions on sea turtle populations.

Acknowledgements. Funding for this project was provided by North Carolina Sea Grant Fishery Resource Grant Program (\#06-FEG-06). All procedures used for this study were approved by University of North Carolina Institutional Animal Care and Use Committee (protocol \#2006-12) and The NOAA Fisheries Office of Protected Resources (permit \#1572). We thank all of the undergraduate and graduate volunteers from the University of North Carolina Wilmington, as well as numerous other volunteers who devoted time and energy in the field. J. Wolfe captained the boat and provided his commercial fishing expertise and assistance in capturing turtles. We thank E. Brandon for many hours of assistance in the field. T. Thorpe gave us information on areas in the lower Cape Fear River where she had encountered sea turtles. Thanks to A. Westgate for satellite data analysis advice. M. Godfrey and W. Cluse of the North Carolina Wildlife Resource Commission provided timely information on regional strandings which helped in our efforts to recover stranded carcasses. B. Dean of the North Carolina Wildlife Resource Commission retrieved the Kemp's ridley turtle that stranded on Oak Island. C. McClellan provided valuable information on techniques and problems associated with tracking juvenile green turtles in nearshore environments. C. Harms provided insight on potential causes of post-release mortality due to gillnet entanglement.

\section{LITERATURE CITED}

Aguirre A, Balazs G, Spraker T, Gross T (1995) Adrenal and hematological responses to stress in juvenile green turtles (Chelonia mydas) with and without fibromapapillomas. Physiol Zool 68:831-854
America CLS (2008) Argos user's manual. www.argossystem.org/manual/ (Accessed 17 July 2010)

Bennett A (1982) The energetic of reptile activity. In: Gans C, Pough F (eds) Biology of the reptila, Vol 13. Academic Press, New York, NY

Berkson H (1966) Physiological adjustments to prolonged diving in the Pacific green turtle (Chelonia mydas agassizii). Comp Biochem Physiol 18:101-119

Bolten AB, Bjorndal K (1992) Blood profiles for a wild population of green turtles (Chelonia mydas) in the southern Bahamas: size-specific and sex-specific relationships. J Wildl Dis 28:407-413

Butler P, Milsom W, Woakes A (1984) Respiratory, cardiovascular and metabolic adjustments during steady state swimming in the green turtle, Chelonia mydas. J Comp Physiol B 154:167-174

Carminati C, Gerle E, Kiehn L, Pisciotta R (1994) Blood chemistry comparison of healthy vs hypothermic juvenile Kemp's ridley sea turtles (Lepidochelys kempi) in the New York bight. Proc 14th Annu Symp Sea Turtle Biol and Conserv. NOAA Tech Mem NMFS-SEFSC 351:203-207

> Chaloupka M, Parker D, Balazs G (2004) Modelling postrelease mortality of loggerhead sea turtles exposed to the Hawaii-based pelagic longline fishery. Mar Ecol Prog Ser 280:285-293

Clarke KR (1993) Non-parametric multivariate analyses of changes in community structure. Aust J Ecol 18:117-143

Clarke KR (1999) Nonmetric multivariate analysis in community-level ecotoxicology. Environ Toxicol Chem 18: $118-127$

Coyne MS, Godley BJ (2005) Satellite Tracking and Analysis Tool (STAT): an integrated system for archiving, analyzing and mapping animal tracking data. Mar Ecol Prog Ser 301:1-7

Crouse D, Crowder L, Caswell H (1987) A stage based population model for loggerhead sea turtles and implications for conservation. Ecology (USA) 68:1412-1423

Eckert K, Bjorndal K, Abreu-Grobois F, Donnelly M (eds) (1999) Research and management techniques for the conservation of sea turtles. IUCN/SSC Marine Turtle Specialist Group Publication No. 4

Epperly S, Braun J, Chester A (1995a) Aerial surveys for sea turtles in North Carolina inshore waters. Fish Bull 93: $254-261$

> Epperly S, Braun J, Veishlow A (1995b) Sea turtles in North Carolina waters. Conserv Biol 9:384-394

Epperly S, Braun J, Chester A, Cross F, Merriner J, Tester P, Churchill J (1996) Beach strandings as an indicator of atsea mortality of sea turtles. Bull Mar Sci 59(2):289-297

Gearhart J (2001) Sea turtle bycatch monitoring of the 2000 fall flounder gillnet fishery of southeastern Pamlico Sound, North Carolina. North Carolina Department of Environment and Natural Resources, Division of Marine Fisheries; Morehead City, NC

Godley BJ, Lima EHSM, Akesson S, Broderick AC and others (2003) Movement patterns of green turtles in Brazilian coastal waters described by satellite tracking and flipper tagging. Mar Ecol Prog Ser 253:279-288

> Harms C, Mallo K, Ross P, Segars A (2003) Venous blood gases and lactates of wild loggerhead sea turtles (Caretta caretta) following two capture techniques. J Wildl Dis 39: 366-374

> Harms C, Eckert SA, Kubis SA, Campbell M, Levenson DH, Crognale MA (2007) Field anaesthesia of leatherback sea turtles (Dermochelys coriacea). Vet Rec 161:15-21

> Hays GC, Broderick AC, Godley BJ, Luschi P, Nichols WJ (2003) Satellite telemetry suggests high levels of fishing- 
induced mortality in marine turtles. Mar Ecol Prog Ser 262:305-309

Hight B, Holts D, Graham J, Kennedy B and others (2007) Plasma catecholamine levels as indicators of the postrelease survivorship of juvenile pelagic sharks caught on experimental drift longlines in the Southern California Bight. Mar Freshw Res 58:145-151

Hoopes L, Landry A, Stabenau E (2000) Physiological effects of capturing Kemp's ridley sea turtles, Lepidochelys kempii, in entanglement nets. Can J Zool 78:1941-1947

Lewison R, Freeman S, Crowder L (2004) Quantifying the effect of fisheries on threatened species: the impact of pelagic longlines on loggerhead and leatherback sea turtles. Ecol Lett 7:221-231

Luschi P, Hays G, Del Seppia C, Marsh R, Papi F (1998) The navigational feats of green sea turtles migrating from Ascension Island investigated by satellite telemetry. Proc Biol Sci 265:2279-2284

Lutcavage M, Lutz P (1991) Voluntary diving metabolism and ventilation in the loggerhead sea turtle. J Exp Mar Biol Ecol 147:287-296

Lutcavage M, Plotkin P, Witherington B, Lutz P (1997) Human impacts on sea turtle survival. In: Lutz P, Musick J (eds) The biology of sea turtles. CRC Press, Boca Raton, FL

Lutz P (1997) Salt, water, and pH balance in sea turtles. In: Lutz P, Musick J (eds) The biology of sea turtles. CRC Press, Boca Raton, FL

Lutz P, Bentley T (1985) Respiratory physiology of diving in the sea turtle. Copeia 671-679

Magnuson J, Bjorndal K, Dupaul W, Graham G and others (1990) Decline of the sea turtles: causes and prevention. National Academy Press, Washington, DC

Manire C, Hueter R, Hull E, Spieler R (2001) Serological changes associated with gill-net capture and restraint in three species of sharks. Trans Am Fish Soc 130:1038-1048

McClellan C, Read A (2010) Confronting the gauntlet: understanding incidental capture of green turtles through finescale movement studies. Endang Species Res 10:165-179

Moyes C, Musyl M, Brill R (2006) Predicting postrelease survival in large pelagic fish. Trans Am Fish Soc 135: 1389-1397

Murphy T, Hopkins-Murphy S (1989) Sea turtle and shrimp fishing interactions: a summary and critique of relevant information. The Center for Marine Conservation, Washington, DC

National Marine Fisheries Service (2002) Federal Register 50 CRF part 223. US Department of Commerce, NOAA, Washington, DC 67:56931-56937

National Marine Fisheries Service SEFSC (Southeast Fisheries Science Center) (2008) Sea turtle research techniques manual. NOAA Tech Memo NMFS-SEFSC-579.

National Research Council (1990) Decline of the sea turtles: causes and prevention. National Academy Press, Washington, DC

Editorial responsibility: Matthew Godfrey, Beaufort, North Carolina, USA
Nelson D (1996) Subadult loggerhead sea turtle (Caretta caretta) behavior in St Marys entrance channel, Georgia, USA. PhD dissertation, College of William and Mary, Virginia Institute of Marine Science, Gloucester Point, VA

Pate P, Division of Marine Fisheries (2006) Proclamation M-72006. Accessed 1 May 2009 www.ncfisheries.net/procs/ procs2k6/M-7-2006.html

Price B (2005) Sea turtle bycatch monitoring of the 2004 fall gillnet fisheries in southeastern Pamlico Sound, North Carolina. North Carolina Department of Environment and Natural Resources, Division of Marine Fisheries, Morehead City, NC

Read A, Foster B, McClellan C, Waples D (2004) Habitat use of sea turtles in relation to fisheries interactions. Final report, N.C. Fishery Resource Grant. Project 02-FEG-05, North Carolina Sea Grant, Morehead City, NC

Rose B (1977) Clinical physiology of acid-base and electrolyte disorders. McGraw-Hill, New York, NY

Santora C (2003) Management of turtle bycatch: can endangered species be protected while minimizing socioeconomic impacts? Coast Manag 31:423-434

Sasso C, Epperly S (2007) Survival of pelagic juvenile loggerhead turtles in the open ocean. J Wildl Manag 71 : $1830-1835$

Seney E (2008) Population dynamics and movements of the Kemp's ridley sea turtle, Lepidochelys kempii, in the northwestern Gulf of Mexico. PhD dissertation, Texas A \& M University, Galveston, TX

Snoddy J, Landon M, Blanvillain G, Southwood A (2009) Blood biochemistry of sea turtles captured in gillnets in the lower Cape Fear River, North Carolina, USA. J Wildl Manag 73:1394-1401

Stabenau E, Vietti K (2003) The physiological effects of multiple forced submergences in loggerhead sea turtles (Caretta caretta). Fish Bull 101:889-899

Stabenau E, Heming T, Mitchell J (1991) Respiratory, acidbase and ionic status of Kemp's ridley sea turtles (Lepidochelys kempii) subjected to trawling. Comp Biochem Physiol A 99:107-111

> Swimmer Y, Arauz R, McCracken M, McNaughton L and others (2006) Diving behavior and delayed mortality of olive ridley sea turtles Lepidochelys olivacea after their release from longline fishing gear. Mar Ecol Prog Ser 323:253-261

- Watson K, Granger R (1998) Hydrodynamic effect of a satellite transmitter on a juvenile green turtle (Chelonia mydas). J Exp Biol 201:2497-2505

Wildlife Computers (2006) SPOT5 user guide. www.wildlife computers.com/Downloads/Documentation/SPOT5\%20 Manual.pdf (accessed 17 July 2010)

Wilson R, McMahon C (2006) Measuring devices on wild animals: What constitutes acceptable practice? Front Ecol Environ 4:147-154

Submitted: August 31, 2009; Accepted: July 27, 2010

Proofs received from author(s): September 15, 2010 